\title{
Screening of Phytochemical Analysis and In vitro Bioactive of Polyherbal Formulation
}

\author{
Vasanth MP, KG Purushotham*
}

\section{Vasanth MP, KG Purushotham*}

Department of Biotechnology, Dr. M.G.R EDUCATIONAL AND RESEARCH INSTITUTE, Chennai-600095, Tamilnadu, INDIA.

\section{Correspondence}

Dr. KG Purushotham

Assistant Professor, Department Biotechnology, Dr.M.G.R Educational and research institute, Chennai-600095, Tamilnadu, INDIA.

Phone no: 9884288313;

E-mail: purushoth13@gmail.com

History

- Submission Date: 23-08-2020;

- Review completed: 10-09-2020;

- Accepted Date: 17-09-2020.

DOI : 10.5530/pj.2020.12.209

Article Available online

http://www.phcogj.com/v12/i6s

\section{Copyright}

(C) 2020 Phcogj.Com. This is an openaccess article distributed under the terms of the Creative Commons Attribution 4.0 International license.

\begin{abstract}
Introduction: Plants have the capability to synthesize various forms of phytochemical compounds as secondary metabolites. Method: In the present investigation phytochemicals such as alkaloids, tannins, glycosides, carbohydrates, reducing sugar, proteins, saponins, flavanoids, phenols, terpenoids and phytosterols were detected in polyherbal formulation $A$. marmelos, G. glabra and $R$. centrifolia. Results: The Total flavonoid, steroids, alkaloids and phenolic content was observed from fruit, root and pettles $1.40 \mathrm{mg} \mathrm{QE} / \mathrm{g} \mathrm{DE}, 12.14 \mathrm{mg} \mathrm{BE} / \mathrm{g} \mathrm{DE}$, $14.40 \mathrm{mg} \mathrm{AE} / \mathrm{g} \mathrm{DE}$ and $99.33 \mathrm{mg}$ GAE/g DE. FTIR spectrum of the polyherbal sample revealed 5 major peaks at $2919.40 \mathrm{~cm}^{-1}, 2357.62 \mathrm{~cm}^{-1}, 1150.56 \mathrm{~cm}^{-1}, 1076.22 \mathrm{~cm}^{-1}$ and $1015.64 \mathrm{~cm}^{-1}$. The antibacterial activity was maximum zone of inhibition $(19 \mathrm{~mm})$ was recorded in $S$. aureus strain and minimum zone of inhibition $(5 \mathrm{~mm})$ was observed in S.mutans strain. The antioxidant study maximum and minimum scavenging DPPH, NOR, H2O2 and SOD activities (\%) of 62.28, $53.68,39.67 \& 43.98$ at $5 \mathrm{mg} / \mathrm{ml}$ and $39.88,36.49,5.9$ and 34.94 at $1 \mathrm{mg} / \mathrm{ml}$ was recorded. The polyherbal sample exhibited significant albumin denaturation, proteinase inhibitory, membrane stabilization and lipid peroxidation inhibitory activities as the maximum inhibition of $46.53 \%, 36.7 \%, 51.9 \%$ and $64.71 \%$ was observed at $500 \mu \mathrm{g} / \mathrm{ml}$. Conclusion: Hence the present studies indicate good antibacterial, antioxidant and anti-inflammatory activities from the medicinal plants, A. marmelos, G. glabra and $R$. centrefolia proves the possibility of its utilization as an additional potent source medicinal uses.
\end{abstract}

Key words: Phyto Chemical, Secondary Metabolites, FTIR, HR-LCMS, Antimicrobial Activity, Antioxidant Activity.

\section{INTRODUCTION}

The finding of new molecules can contribute to the development of basic scientific concepts, lead to valuable drug oriented compounds and suggest possible new pharmacological reagents. The high demand for medicinal plants is associated with their physicochemical properties and biological activities and has led to the emergence of phytochemicals as commercially important compounds that have found usefulness in food, cosmetics, and pharmaceutical industries. Secondary metabolites often have unique biological actions and thus deserve special attention. In addition, some compounds from plant parts show significant biological activity at an extremely low concentration. Medicinal plants have been used in traditional medicine in meeting the health needs of people in India. In India, research emphasizing discovery of medicinal plants with antimicrobial, antioxidant, anti-inflammatory and anticancer activities is ongoing and recognition has been given to the application of medicinal plants in the treatment and management of several diseases, including heart diseases. The fruit is also diuretic, being effective in the treatment of dropsy and renal stones. The root is purgative and in large dose is said to be emetic ${ }^{1}$. Antimicrobial polyherbal (AMP) are important components of the host innate immune response against microbial invasion. AMP is usually characterized by their small-size, heat-stability and broad range of antimicrobial activity.Bioantioxidants are necessary components of all tissue and cells of living organisms, where their normal physiological concentrations maintain free-radical autooxidation processes at a low stationary level ${ }^{2}$. Plant polyerbal product anti-inflammatory compounds are the practical examples of these medications which are associated with adverse effects while in practice our purpose is to apply minimum effective dose by the highest efficiency with the least adverse effects ${ }^{3}$. In present study was designed to examine the total polyherbal formulation and phytochemical analysis of aqueous extract of fruit, root and pettles of $A$. marmelos, G. glabra and R. centerifolia were screened for antimicrobial, antioxidant and anti-inflammatory properties using standard methods. The findings from this work may add to the overall value of the medicinal potential of the plants.

\section{MATERIALS AND METHODS}

The plant was collected in January 2018 from Rumi herbals pvt ltd. The plant was identified by their common names Aegle marmelos (Common Name - Bael); (Family - Rutaceae); (Part - fruit), Glycyrrihza glabra (Common Name - Liquorice); (Family - Fabaceae); (Part - roots), Rosa centrifolia (Common Name - White rose); (Family - Rosaceae); (Part - pettles) and later it was compared with the herbarium of the Department of Studies in Botany, pachaiyappa's college tamilnadu, Chennai. 


\section{Aqueous extract}

Initially, distilled water (Aq) $(100 \mathrm{~mL})$ was added to the polyherbal formulation material $(40 \mathrm{~g})$, the mixture was maintained on a rotary incubator $\left(220 \mathrm{rpm}, 24 \mathrm{~h}, 22^{\circ} \mathrm{C}\right)$. After this period, the mixture was filtered using Whatman $\mathrm{n}^{\circ} 1$ filter paper and centrifuged at $5000 \mathrm{rpm}$ for 15 minutes. The supernatant was collected giving rise to the aqueous extracts, it was maintained at a temperature of $4^{\circ} \mathrm{C}$ until used in the bioassays.

\section{Phytochemical screening}

Aqueous extracts of polyherbal formulation A. marmelos, G. glabra and $R$. centrifolia were tested for the presence of alkaloids, tannins, glycosides, carbohydrates, reducing sugar, proteins, saponins, flavanoids, phenols, terpenoids and phytosterols according to a methodology ${ }^{4}$.The qualitative results were expressed as presence/ positive reaction $(+)$ weakly positive and absence /negative reaction (-) of phytochemicals.

\section{Determination of total flavonoid contents}

The total flavonoï contents of the polyherbal formulation extracts were quantified by spectrophotometric (Thermo Fisher Scientific, Genesys, Madison, USA) measurement of the absorbance according to the FolinCiocalteu, using the aluminum chloride and by the vanillin methods $^{5}$

\section{Determination of steroids contents}

In this test acetic anhydride $(2 \mathrm{ml})$ was mixed to $0.5 \mathrm{~g}$ of each crude extracts of polyherbal formulation A. marmelos, G. glabra and $R$. centrifolia followed by adding of $2 \mathrm{ml}$ of $\mathrm{H}_{2} \mathrm{SO}_{4}$. The color changed from violet to green or blue in some samples authenticates the presence of steroids. ${ }^{6}$

\section{Determination of total alkaloids}

Exactly $1 \mathrm{~g}$ of the polyherbal sample was weighed into a $250 \mathrm{ml}$ beaker and $40 \mathrm{ml}$ of $10 \%$ acetic acid in ethanol was added and covered and allowed to stand for $4 \mathrm{~h}$. The whole solution was allowed to settle and the precipitate was collect washed with dilute ammonium hydroxide and then filtered. The residue is the alkaloid, which was dried and quantified. $^{6}$

\section{Determination of total phenolic content}

Total phenolic content (TPC) in extracts was determined by FolinCiocalteu's colorimetric method.?

\section{Fourier Transform Infra Red (FT-IR) analysis}

FT-IR spectrum of crude extract was taken relied on a Bio-Rad FTIR-40 model, USA. Sample $(10 \mu \mathrm{g})$ was mixed with $100 \mathrm{mg}$ of dried $\mathrm{KBr}$ and compressed to prepare as a salt disc $(10 \mathrm{~mm} \mathrm{dm})$ for reading the spectrum further.

\section{HR-LCMS}

The total content of phyto-chemicals in extracts was separation according to the method. Mass spectrometric analysis was performed on a Shimadzu mass spectrometer.

\section{Antimicrobial activity}

Plant polyherbal crude extract was tested for inhibition against the human pathogenic bacteria. Microbial assay were carried out by well diffusion technique. ${ }^{8}$

\section{Antioxidant Activities}

Scavenging ability on 1,1-diphenyl-2-picrylhydrazyl radicals (DPPH)

The scavenging activity of the DPPH free-radical was assayed according to the method. ${ }^{9}$

\section{NO Reduction assay}

The NO Reduction assayof polyherbal was assessed by the modified method. $^{10}$

\section{Hydroxyl radical scavenging activity}

The scavenging activity of polyherbal against the hydroxyl radical was investigated using Fenton's reaction $\left(\mathrm{Fe}^{2+}+\mathrm{H}_{2} \mathrm{O}_{2} \rightarrow \mathrm{Fe}^{3+}+\mathrm{OH}^{-}+\mathrm{OH}\right)$. Hydroxyl radicals were generated using a modified. ${ }^{11}$

\section{Superoxide radical scavenging activity}

The superoxide radical scavenging abilities of polyherbal were assessed by the modified method. ${ }^{12}$

\section{Anti-inflammatory activity}

\section{Preparation of Raw 246.7 macrophages cell suspension}

A subculture of Raw 246.7 macrophages in Dulbecco's Modified Eagle's Medium (DMEM) was trypsinized separately, after discarding the culture medium. To the disaggregated cells in the flask $25 \mathrm{~mL}$ of DMEM with $10 \%$ FCS was added. The cells suspended in the specific medium by gentle passage with the pipette and the cells homogenized.

\section{Seeding of cells}

One $\mathrm{mL}$ of the homogenized cell suspension was added to each well of a 24 well culture plate along with different concentration of sample AM dry extract $(0$ to $400 \mu \mathrm{g} / \mathrm{mL})$ and incubated at $37^{\circ} \mathrm{C}$ in a humidified $\mathrm{CO} 2$ incubator with $5 \% \mathrm{CO} 2$. After $48 \mathrm{hrs}$ incubation the cells were observed under an inverted tissue culture microscope. With $80 \%$ confluence of cells cytotoxic assay was carried out.

\section{Cytotoxicity assay}

The assay was carried out using (3-(4, 5-dimethyl thiazol-2yl)-2, 5- diphenyl tetrazolium bromide (MTT). MTT assay is cleaved by mitochondrial Succinate dehydrogenase and reductase of viable cells, yielding a quantifiable purple product formazan. All wells were removed the content using pipette and $100 \mu \mathrm{L}$ SDS in DMSO were added to dissolve the formazan crystals, absorbance's were read in Lark LIPR9608 micro plate reader at $540 \mathrm{~nm}^{13}$

\section{Inhibition of nitric oxide (NO) production}

\section{Cell culture}

The RAW 264.7 macrophage cell lines were cultured in plastic culture flasks in Dulbecco's Modified Eagle's Medium containing l-glutamine supplemented with $10 \%$ foetal calf serum (FCS) and $1 \%$ antibiotic solution (Gibco, USA) solution under $5 \% \mathrm{CO} 2$ at $37^{\circ} \mathrm{C}$, and were split twice a week. Cells were seeded in 96 well-microtitre plates and were activated by incubation in medium containing LPS $(5 \mu \mathrm{g} / \mathrm{mL})$ and various concentrations of extracts dissolved sterile DMEM medium. ${ }^{14}$

\section{Measurement of nitrite}

Nitric oxide released from macrophages was assessed by the determination of nitrite concentration in culture supernatant using the Griess reagents. The absorbance of the resultant solutions in the wells of the microtitre plate was determined with a microtitre plate reader (Readwel touch, Micro plate Reader, India) after $10 \mathrm{~min}$ at $550 \mathrm{~nm}$. 


\section{Albumin Denaturation Assay (ADA)}

The albumin denaturation assay of polyherbal was studied by using inhibition of albumin denaturation technique which was studied. ${ }^{15}$

\section{Proteinase Inhibitory Activity (PIA)}

The proteinase inhibitory activity test was performed according to the modified method. ${ }^{16}$

\section{HRC Membrane Stabilization Activity (HRC)}

The membrane stabilization activity test was performed according to the modified method. ${ }^{17}$

\section{Lipid peroxidation Activity (LPA)}

The lipid peroxidation activity of polyherbal was assessed by the standard method. ${ }^{18}$

\section{RESULTS}

\section{Phytochemical screening}

Alkaloids, tannins, glycosides, carbohydrates, reducing sugar, proteins, saponins, flavanoids, phenols, terpenoids and phytosterols were detected (Table 1).

\section{Determination of total flavonoid, steroids, alkaloids and phenolic contents}

The Total flavonoid, steroids, alkaloids and phenolic content was observed in polyherbal formulation A. marmelos, G. glabra and $R$. centrifolia from fruit, root and pettles1.40mg QE/g DE, $12.14 \mathrm{mg} \mathrm{BE} / \mathrm{g}$ $\mathrm{DE}, 14.40 \mathrm{mg} \mathrm{AE} / \mathrm{g} \mathrm{DE}$ and $99.33 \mathrm{mg} \mathrm{GAE} / \mathrm{g} \mathrm{DE}$.

\section{FTIR spectral analysis}

FTIR spectrum of the polyherbal sample revealed 5 major peaks at $2919.40 \mathrm{~cm}^{-1}, 2357.62 \mathrm{~cm}^{-1}, 1150.56 \mathrm{~cm}^{-1}, 1076.22 \mathrm{~cm}^{-1}$ and $1015.64 \mathrm{~cm}$ ${ }^{1}$ and the remaining peaks are closely lying between $1015.64 \mathrm{~cm}^{-1}$ and $3851.67 \mathrm{~cm}^{-1}$ (Figure 1).The signals at $2919.40 \mathrm{~cm}-1$ correspond to $\mathrm{C}-\mathrm{H}$ stretch in primary and secondary carboxylic bands. The FT-IR spectrum of the polyherbal the ester band started from $1150.56 \mathrm{~cm}^{-1}$ respectively. The anhydrides group is represented by a band in $1076.22 \mathrm{~cm}^{-1}$ and $1015.64 \mathrm{~cm}^{-1}$ the carbon group at $1653 \mathrm{~cm}^{-1}$.

\section{Liquid chromatography coupled to mass spectrometry (HR LC/MS)}

The present study is the first to investigate and identify phytochemical compounds of polyherbal extract from A. marmelos, G. glabra and $R$. centrifolia (Figure 2). The predominant compounds of fruit, root and pettles . Norcotinine $(\mathrm{Rt}=0.798 \mathrm{~min})$ at $\mathrm{m} / \mathrm{z}=162$,Lupanyl acid $(\mathrm{Rt}=0.813$ $\mathrm{min})$ at $\mathrm{m} / \mathrm{z}=252$,Agmatine $(\mathrm{Rt}=0.826 \mathrm{~min})$ at $\mathrm{m} / \mathrm{z}=130$, Lactulose $(\mathrm{Rt}=0.955 \mathrm{~min})$ at $\mathrm{m} / \mathrm{z}=342$, Tranexamic acid $(\mathrm{Rt}=1.088 \mathrm{~min})$ at $\mathrm{m} /$ $\mathrm{z}=157$,Nomifensin $(\mathrm{Rt}=4.006 \mathrm{~min})$ at $\mathrm{m} / \mathrm{z}=238$,Piin $(\mathrm{Rt}=5.883 \mathrm{~min})$ at $\mathrm{m} / \mathrm{z}=564$,Hoifolin $(\mathrm{Rt}=6.333 \mathrm{~min})$ at $\mathrm{m} / \mathrm{z}=578$,Phenylpropiolic acid $(\mathrm{Rt}=6.673 \mathrm{~min})$ at $\mathrm{m} / \mathrm{z}=146$,Citropten $(\mathrm{Rt}=6.673 \mathrm{~min})$ at $\mathrm{m} / \mathrm{z}=146$, Gummiferol $(\mathrm{Rt}=8.187 \mathrm{~min})$ at $\mathrm{m} / \mathrm{z}=286$, Genkwanin $(\mathrm{Rt}=8.572 \mathrm{~min})$ at $\mathrm{m} / \mathrm{z}=284$,Formononetin ( $\mathrm{Rt}=10.3 \mathrm{~min})$ at $\mathrm{m} / \mathrm{z}=268$,Rifampin $(\mathrm{Rt}=10.83 \mathrm{~min})$ at $\mathrm{m} / \mathrm{z}=822$ and Crotamiton $(\mathrm{Rt}=12.713 \mathrm{~min})$ at $\mathrm{m} /$ $\mathrm{z}=203$.

\section{Antimicrobial activity}

The zone of inhibition in different bacterial strains against polyherbal extraction is shown in (Figure 3 and Plate I). Among the various bacterial strains maximum zone of inhibition $(19 \mathrm{~mm})$ was recorded in Staphylococcus aureus strain and minimum zone of inhibition $(5 \mathrm{~mm})$ was observed in Streptococcus mutans strain.

\section{Antioxidant Activities}

In the present study maximum and minimum scavenging (DPPH) activity (\%) of 62.28 at $5 \mathrm{mg} / \mathrm{ml}$ and 39.88 at $1 \mathrm{mg} / \mathrm{ml}$ was recorded in the polyherbal sample (Figure 4). The maximum and minimum NO reduction ability (\%) of 53.68 at $5 \mathrm{mg} / \mathrm{ml}$ and 36.49 at $1 \mathrm{mg} / \mathrm{ml}$ was reported in polyherbal sample. The maximum and minimum scavenging (H2O2) activity (\%) of 39.67 at $5 \mathrm{mg} / \mathrm{ml}$ and 5.9 at $1 \mathrm{mg} /$ $\mathrm{ml}$ was reported in polyherbal sample. The maximum and minimum scavenging (SOD) activity (\%) of 43.98 at $5 \mathrm{mg} / \mathrm{ml}$ and 34.94 at $1 \mathrm{mg} /$ $\mathrm{ml}$ was reported in polyherbal sample. The antioxidant activity was comparable with standard ascorbic acid.

\section{Anti-inflammation assay}

The in-vitro cytotoxicity activity results of the polyherbal extract sample against Raw246.7 macrophages cells were triggered of cytotoxicity significantly with the increasing of sample concentration and it was observed. In this cell lines, cytotoxicity assay was observed in tested sample concentrations in 48 hours treatment, it also observed that increased concentration of test samples shown increased cytotoxicity over the tested cell lines (Figure 5). It was evident that the less cytotoxicity of the test sample showed no cell disintegration and migration after $48 \mathrm{~h}$ of treatment against the selected tested cell lines effect. It was calculated that the IC50 of the test sample AM dry extract against Raw 246.7 macrophages cells was $326.274 \mu \mathrm{g} / \mathrm{ml}$.

The inhibitory activity of the polyherbal extract on NO production by induced RAW264.7 macrophage cell lines. Sample polyherbal dry extract had the best inhibitory activity on NO production $(32.79 \%$ inhibition / $75.51 \%$ cell viability) at $12.5 \mu \mathrm{g} / \mathrm{mL}$ (Figure 6).

Table 1: Phytochemical prospection of aqueous extracts from polyherbal samples.

\begin{tabular}{|c|c|c|c|c|c|}
\hline S.No & Screening & A. marmelos & G. glabra & R. centifolia & VIco1 \\
\hline 1 & Alkaloids & + & + & - & + \\
\hline 2 & Tannins & + & + & - & + \\
\hline 3 & Glycosides & + & + & + & + \\
\hline 4 & Carbohydrates & + & + & - & + \\
\hline 5 & Reducing sugar & + & + & + & + \\
\hline 6 & Proteins & + & + & + & + \\
\hline 7 & Saponins & - & + & + & + \\
\hline 8 & Flavanoids & + & + & + & + \\
\hline 9 & Phenols & + & + & - & + \\
\hline 10 & Terpenoids & + & - & - & + \\
\hline 11 & Phytosterols & + & + & + & + \\
\hline
\end{tabular}



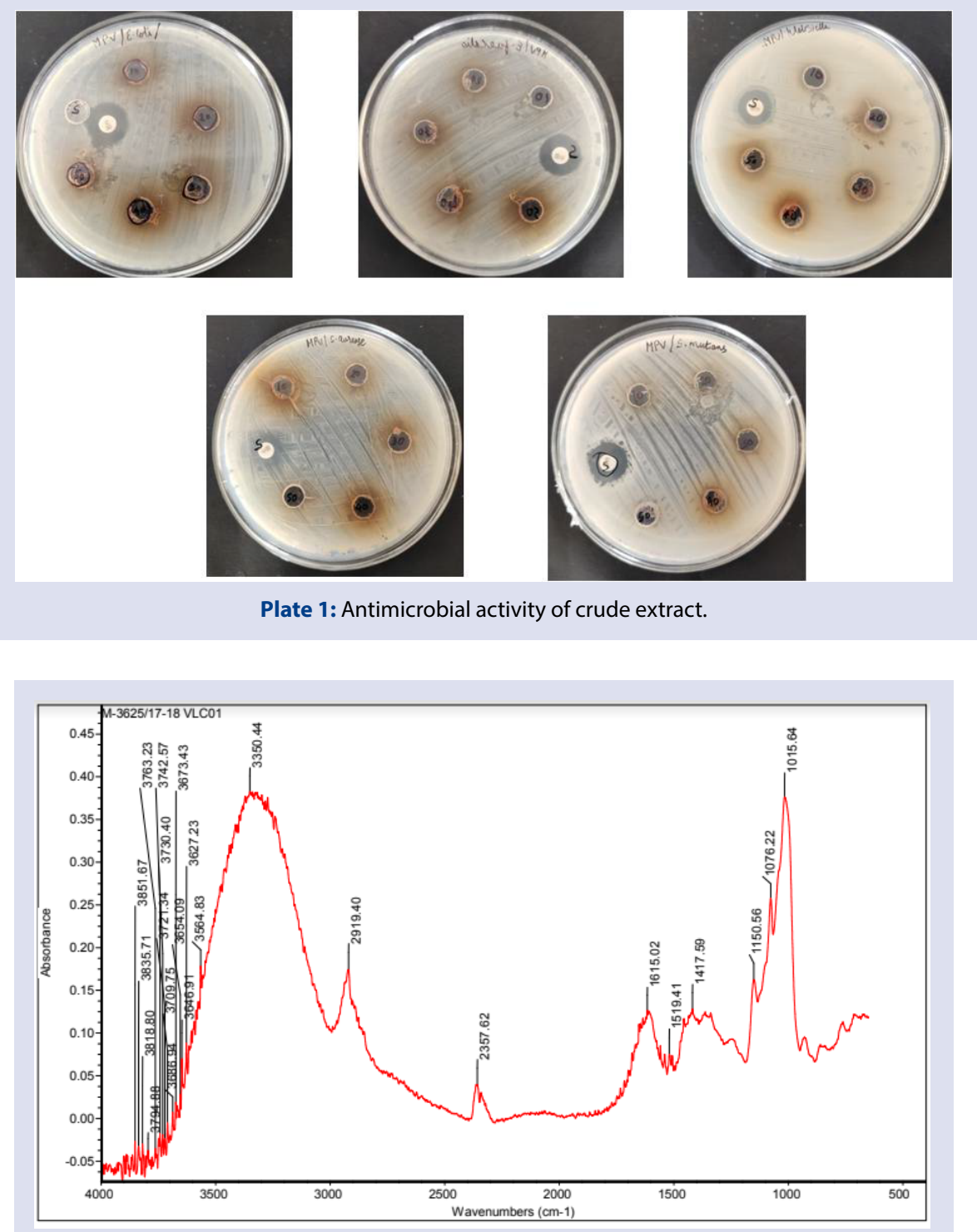

Figure 1: FTIR spectrum of polyherbal sample.

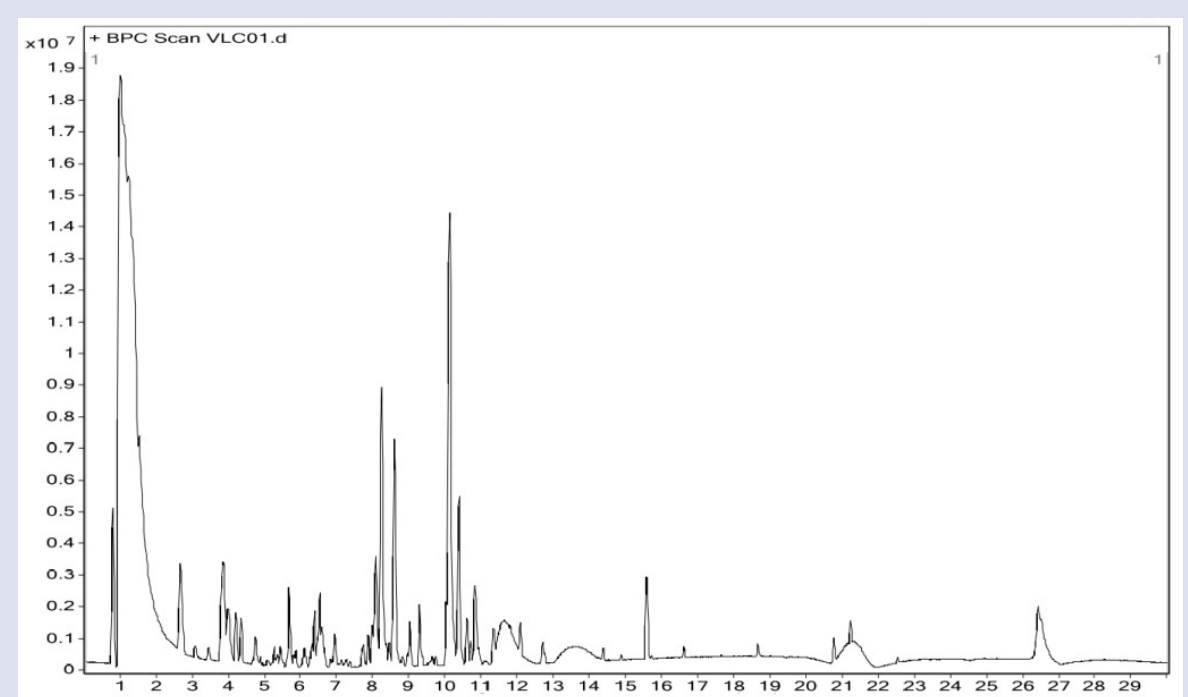

Figure 2: LC/MS characteristics of phytochemical compounds. Compounds listed in order of retention time; $\mathrm{Rt}=$ retention time (as $\mathrm{min})$. 


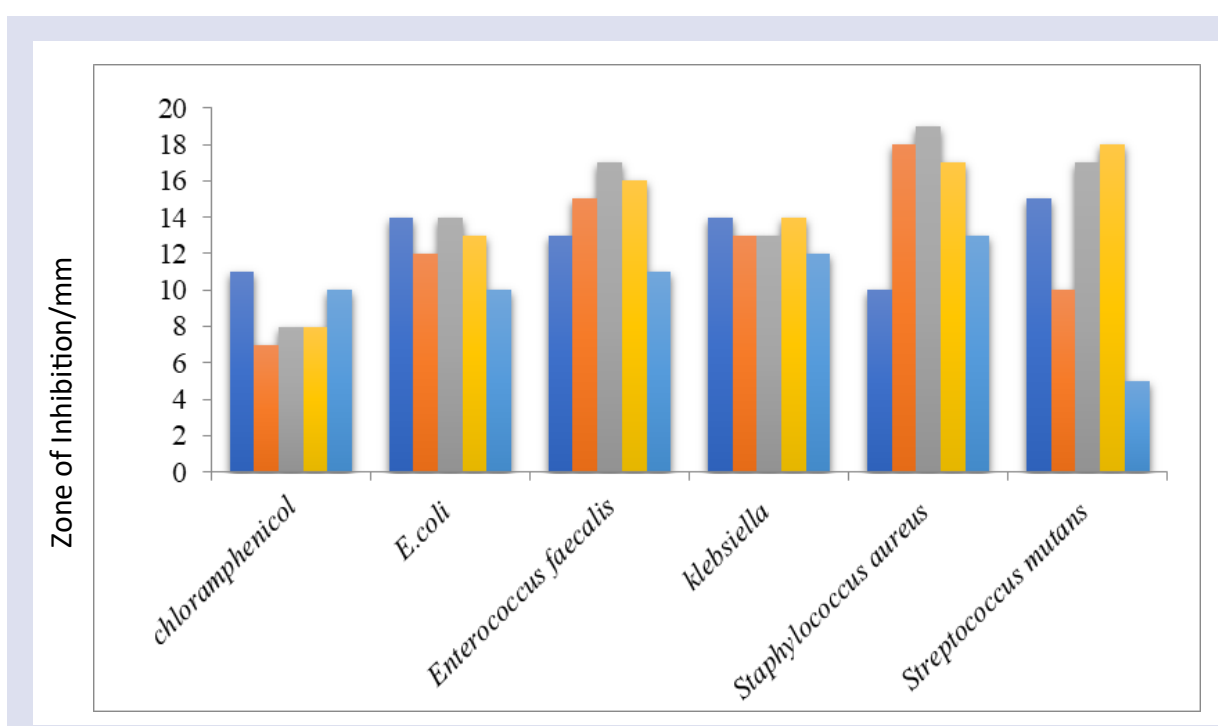

Figure 3: Antimicrobial activity of crude extract.

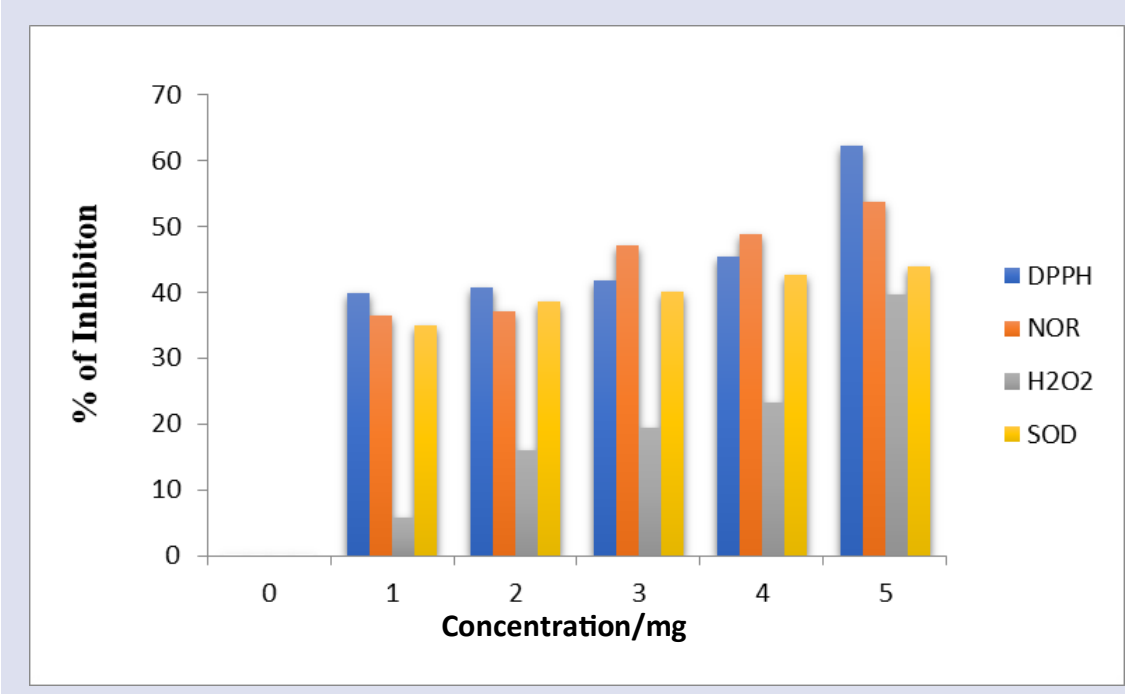

Figure 4: Scavenging activity of polyherbal sample.

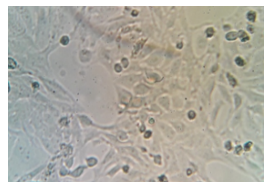

Control

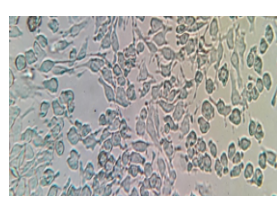

Conc. $200 \mu \mathrm{g} / \mathrm{mL}$

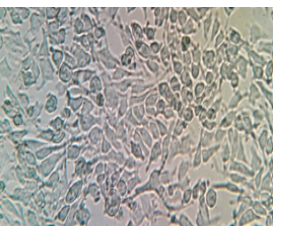

Conc. $400 \mu \mathrm{g} / \mathrm{mL}$

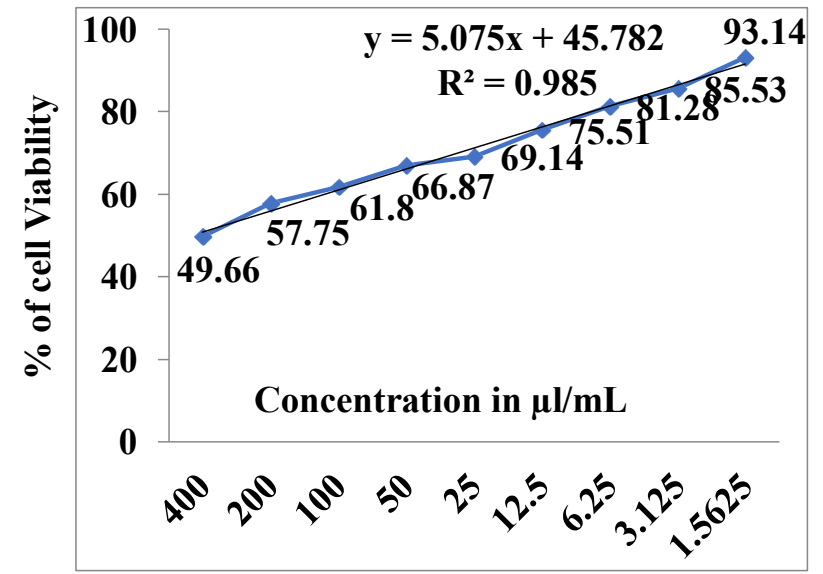

Figure 5: Cytotoxicity effect of sample against Raw 246.7macrophages Cell lines. 

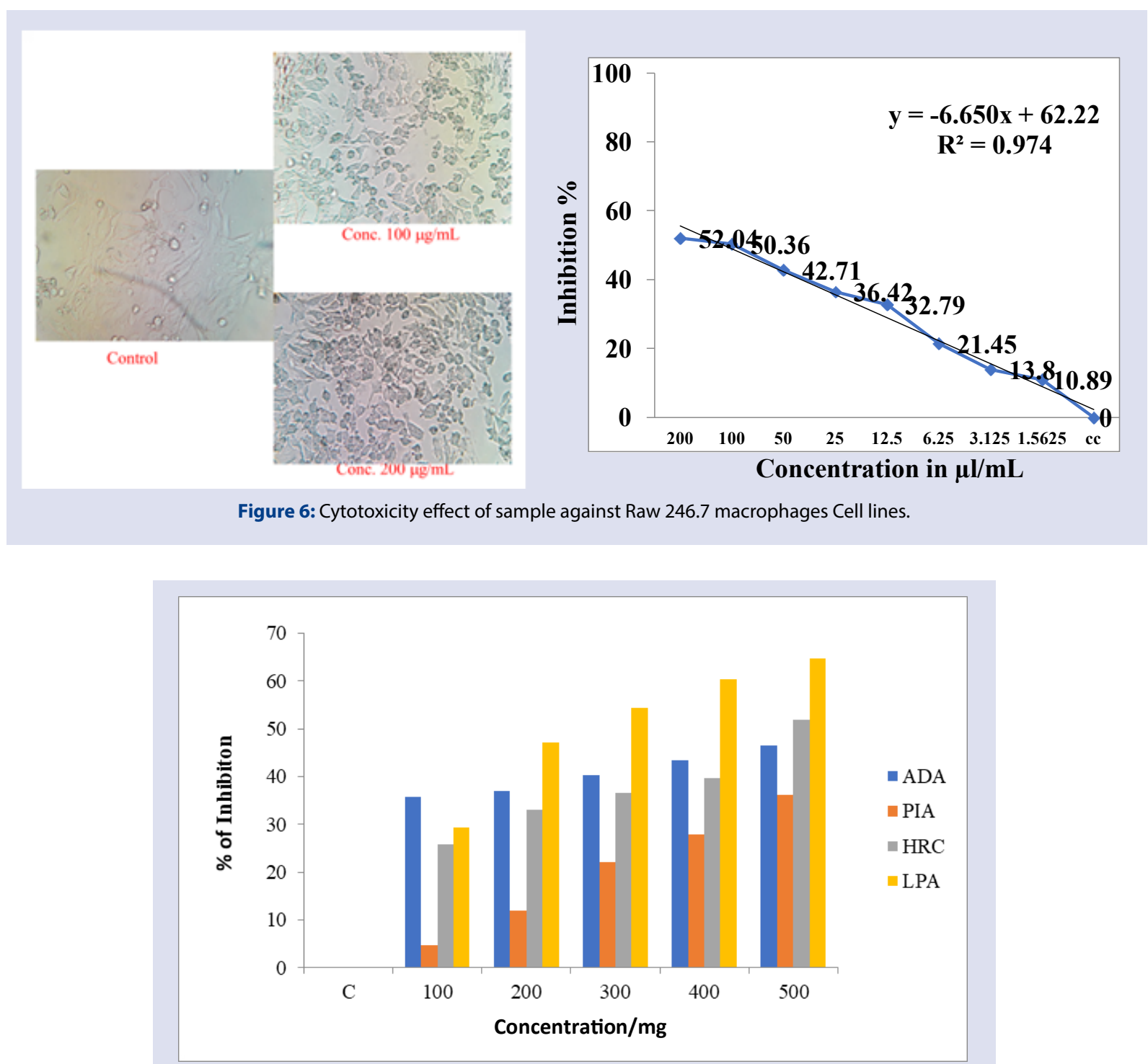

Figure 7: Effect of aqueous extracts of polyherbal on albumin denaturation, proteinase inhibitory, membrane stabilization and lipid peroxidation inhibitory activities.

In the present investigation the polyherbal sample exhibited significant albumin denaturation, proteinase inhibitory, membrane stabilization and lipid peroxidation inhibitory activities at different concentrations as determined. Maximum inhibition of $46.53 \%, 36.7 \%, 51.9 \%$ and $64.71 \%$ was observed at $500 \mu \mathrm{g} / \mathrm{ml}$ (Figure 7).

\section{DISCUSSION}

In India, medicinal plants phytochemicals are widely used by all sections of people either directly as folk remedies or in different indigenous systems of medicine or indirectly in the pharmaceutical preparations of modern medicines. Plants are considered as potent source of biological active compounds that are able to produce different important secondary metabolites described with great biological activities. In the past few decades several investigations are observed that the plants polyherbal product and the phyto-chemicals derivatives have received the most attention of researchers. In present study was designed to evaluated the total polyherbal formulation and phytochemical analysis of aqueous extract of fruit, root and pettles of A. marmelos, G. glabra and $R$. centrifolia were screened for antimicrobial, antioxidant and antiinflammatory properties using standard methods.
In the present investigation determination of phytochemicals such as alkaloids, tannins, glycosides, carbohydrates, reducing sugar, proteins, saponins, flavanoids, phenols, terpenoids and phytosterols were observed. Phytochemicals present in different parts of the plants, such as in the root, stem, leaf, flower, fruit and seed. Phyto- chemicals has long been documented that fruits and vegetables are essential toa healthy and well balanced diet required for healthy living and that high consumption is beneficial to health in combating the onset of cancer, coronary disease, inflammation, arthritis, antibacterial compounds, antioxidant, immune system decline, brain dysfunction and cataracts. The aqueous extract all Polyherbal presented positive reaction $(+)$ for the presence of phytochemicals.

The aqueous extract was the only one that presented flavanonols, which are considered partially polar flavonoids and moderately soluble in polar solvents, such as water ${ }^{19}$. Saponins were found only in the aqueous extract and it is known that saponins have high polarity. The phenolic compounds, condensed tannins were detected when more polar solvents were used, such as ethanol, methanol and water ${ }^{20}$.The different kinds of secondary metabolites detected in A. marmelos, G. glabra and $R$. centrifolia leaves extracts, in the present work, are in 
agreement with the reported in the previous literature for other species of the same class. Polyherbal determined with phytochemical reported the presence of steroids alkaloids, tannins, glycosides, carbohydrates, reducing sugar, proteins, saponins, flavanoids, phenols, terpenoids and phytosterols ${ }^{21}$ which may be related to the biological activities found in the present studies.

In the present evaluation the FTIR spectrum of the polyherbal sample revealed 5 major peaks at $2919.40 \mathrm{~cm}^{-1}, 2357.62 \mathrm{~cm}^{-1}, 1150.56 \mathrm{~cm}$ ${ }^{1}, 1076.22 \mathrm{~cm}^{-1}$ and $1015.64 \mathrm{~cm}^{-1}$ and the remaining peaks are closely lying between $1015.64 \mathrm{~cm}^{-1}$ and $3851.67 \mathrm{~cm}^{-1}$.The signals at 2919.40 $\mathrm{cm}-1$ correspond to $\mathrm{C}-\mathrm{H}$ stretch in primary and secondary carboxylic bands. The FT-IR spectrum of the polyherbal the ester band started from $1150.56 \mathrm{~cm}^{-1}$ respectively. The anhydrides group is represented by a band in $1076.22 \mathrm{~cm}^{-1}$ and $1015.64 \mathrm{~cm}^{-1}$ the carbon group at $1653 \mathrm{~cm}^{-1}$ ${ }^{22}$ was probably the first researcher to suggest the possibility of using infrared spectroscopy for biological sample. The plants phytochemical compounds are different in molecular structure and characterization. Analysis of the FT-IR spectrum showed typical absorption bands corresponding to $\mathrm{N}-\mathrm{H}$ stretching of proteins and peptide bonds, giving solid evidence that the substance contained a peptide in its structure. Again the FT-IR spectral analysis of the polyherbal phytochemical from A. marmelos, G. glabra and R. centerifolia showed more or less same number of peaks, lying within the same range of values of the commercial phytochemical used as a standard.

The present study is the predominant compounds of fruit, root and pettles Norcotinine $(\mathrm{Rt}=0.798 \mathrm{~min})$ at $\mathrm{m} / \mathrm{z}=162$, Lupanyl acid $(\mathrm{Rt}=0.813$ $\mathrm{min}$ ) at $\mathrm{m} / \mathrm{z}=252$,Agmatine $(\mathrm{Rt}=0.826 \mathrm{~min})$ at $\mathrm{m} / \mathrm{z}=130$, Lactulose $(\mathrm{Rt}=0.955 \mathrm{~min})$ at $\mathrm{m} / \mathrm{z}=342$, Rifampin $(\mathrm{Rt}=10.83 \mathrm{~min})$ at $\mathrm{m} / \mathrm{z}=822$ and Crotamiton $(\mathrm{Rt}=12.713 \mathrm{~min})$ at $\mathrm{m} / \mathrm{z}=203$ reported ${ }^{10}$ that the accumulate compounds of E. glaucophyllum flowers extract were: quinic acid $(\mathrm{Rt}=1.7 \mathrm{~min})$ at $\mathrm{m} / \mathrm{z}=191$, rutin $(\mathrm{Rt}=21.8 \mathrm{~min})$ at $\mathrm{m} / \mathrm{z}=609$, gallic acid $(\mathrm{Rt}=2.8 \mathrm{~min})$ at $\mathrm{m} / \mathrm{z}=169$ and Apegenin-7-o-glucoside $(\mathrm{Rt}=28.4 \mathrm{~min})$ at $\mathrm{m} / \mathrm{z}=431$.The phytochemical characteristics of $A$. marmelos, G. glabra and $R$. centerifolia extract proved to be very similar to plants.

The use of medicinal plants plays a crucial role in covering the basic health needs in developing countries and these plants may offer a new source of antibacterial, antifungal and antiviral agents with significant activity against infective microorganisms. ${ }^{10}$ In the present investigation the zone of inhibition in different bacterial strains the maximum zone of inhibition $(19 \mathrm{~mm})$ was recorded in $S$. aureus strain and minimum zone of inhibition $(5 \mathrm{~mm})$ was observed in $S$. mutansstrain from $A$. marmelos, G. glabra and R. centerifolia.

Generally, plants extracts are usually more active against gram positive bacteria than gram negative bacteria. According ${ }^{25}$ gram negative bacteria are more resistant to plants extract compared to gram positive bacteria. This may be due to the permeability barrier provided by the cell wall or to the membrane accumulation mechanism. This is in support of the present finding which showed that only polyherbal phytochemical from A. marmelos, G. glabra and R. centerifolia was effective on the growth of S.aureus. The positive control (chloramphenicol) was showed activity against the bacterial strains tested and the maximum activity $11 \mathrm{~mm}$. In addition, ethanol extracts of this herb have been reported to be effective against a-Streptococcus group ${ }^{26}$. The use of fruit, leave and root agents for medicinal benefits has played an important role in anti-bacterial agents derived from terrestrial plants. The polyherbal phytochemical from A. marmelos, G. glabra and R. centerifolia the aqueous extracts showed significant antimicrobial activity when compared with control (antibiotic chloramphenicol).

Plants antioxidant agents like phenolic acids, polyphenols and flavonoids are capable to scavenge free radicals such as peroxide, hydroperoxide or lipid peroxyl and thus inhibit the oxidative mechanism that lead to degenerative diseases. In the present study maximum and minimum scavenging (DPPH, NOR, $\mathrm{H} 2 \mathrm{O} 2$ and SOD) activities (\%) of 62.28, $53.68,39.67 \& 43.98$ at $5 \mathrm{mg} / \mathrm{ml}$ and $39.88,36.49,5.9$ and 34.94 at $1 \mathrm{mg} /$ $\mathrm{ml}$ was recorded in the polyherbal sample. In recent years, there has been an increasing interest in finding natural antioxidants, since they can protect advancement of many chronic diseases. ${ }^{27}$ The antioxidant activity of phytochemical may be attributed to various mechanisms, which includes prevention of chain initiation, binding of transition metal ion catalysts, decomposition of peroxides, reductive capacity and radical scavenging. The scavenging ability of the E. glaucophyllum extracts samples (leaves and flowers) on DPPH free radical was determined $25.2 \pm 1.9 \%$ to $91.9 \pm 0.1 \%{ }^{10}$. The effect of antioxidants on DPPH radical scavenging was due to their hydrogen donating power The present results indicate that the phytochemical was better hydroxyl radical scavenger. Antioxidants of 0.04, 0.31, 0.58, 2.30 and $0.054 \mathrm{mg} /$ $\mathrm{ml}$ were recorded for Psidium guajava, Magniferaindica, Caricapapaya, Vernonia amygdalina and Vitamin C. When the results are compared, the polyherbal had stronger scavenging activity for superoxide radical than control. The mechanism of these results is that the inner structure of phytochemical is severely disrupted by the introduction of grafted polymer chains after modification. The ability to form hydrogen bond declines sharply and the hydroxyl and sulfate groups are activated, so this is helpful to the reaction with superoxide anion.

Albumin denaturation and proteinase inhibitory was effective in the maximum inhibition of $71 \%$ and $53 \%$ was observed at $500 \mu \mathrm{g} /$ $\mathrm{ml}$ reported ${ }^{28 .}$ The Wedeliatrilobata leaf and stem ethanol extract also showed anti-inflammatory activity by inhibiting the heat induced albumin denaturation and red blood cells membrane stabilization with 87.14 and 86.76 and $78.11,74.17 \mathrm{~g} / \mathrm{ml}$ respectively ${ }^{29} \mathrm{In}$ the present investigation the polyherbal sample exhibited significant albumin denaturation, proteinase inhibitory, membrane stabilization and lipid peroxidation inhibitory activities at different concentrations as determined. Maximum inhibition of $46.53 \%, 36.7 \%, 51.9 \%$ and $64.71 \%$ was observed at $500 \mu \mathrm{g} / \mathrm{ml}$. All doses of the extract tested were effective in reducing polyherbal throughout the experiment. The present concluded that aqueous extract of the plant parts had appreciable antiinflammatory activity and thus justifies its use in traditional medicine in the treatment of inflammatory diseases.

In the present investigation the in-vitro cytotoxicity activity results of the polyherbal dry extract sample was calculated that the IC50 of the test sample polyherbal dry extract against Raw 246.7macrophages cells was $326.274 \mu \mathrm{g} / \mathrm{ml}$. The inhibitory activity of the AM dry extract on NO production by induced RAW264.7 macrophage cell lines is the best inhibitory activity on NO production $(32.79 \%$ inhibition / $75.51 \%$ cell viability) at $12.5 \mu \mathrm{g} / \mathrm{mL}$. Sample AM dry extract with good inhibitory activity on NO production and a low cytotoxicity are more useful. Release of NO promotes inflammation, therefore extracts that could act as scavengers of $\mathrm{NO}$, or inhibitors of its production, especially with corresponding low cytotoxicity could be used to mitigate the propagation of inflammation by NO. ${ }^{30}$ Showed a maximum of $46.86 \%$ oedema inhibition at $3 \mathrm{~h}$. at the dose of $200 \mathrm{mg} / \mathrm{kg}$ and the anti-inflammatory effect tested for $3 \mathrm{~h}$. for Glycyrrhiza glabra. Antiinflammatory study showed that the extracts of Terminaliabellarica (73.34\%) and T. chebula (74.81\%) showed significant COX-2 selective inhibition as compared to other samples. In the present report the cytotoxicity determination study of aquouse fraction of selected medicinal plants indicates that the selected samples have no effect on cell viability. Present findings provide technical evidence to support phytochemicals medicinal uses and indicate a promising potential for the development of an anti-inflammatory agent from A. marmelos, G. glabra and $R$. centrifolia plants.

Plants have the capability to synthesize various forms of phytochemical compounds such as primary and secondary metabolites, many of which have been identified and continue to be relevant in the treatment of 
complicated disease conditions in the Indian setting. Interestingly, researcher have examined some of these Indian medicinal plants and acknowledged their biological and therapeutic activities. Hence the present studies good antibacterial, antioxidant and anti-inflammatory activities from the medicinal plants, A. marmelos, G. glabra and R.centrifoliaproves the possibility of its utilization as an additional potent source medicinal use.

\section{ACKNOWLEDGEMENT}

I thank A. C. S. Arun Kumar, President, Dr. M. G. R. Educational and Research Institute University for the chancellor fellowship. Rumi herbals pvt ltd supporting for plant materials.

\section{CONFLICTS OF INTEREST}

None.

\section{REFERENCES}

1. Karawya, M.S, M.M. Ammar, M.S. Hifnawy, S. AL-Okbi, D.A. Mohamed, A.A. EL-Anssary.Phytochemical study and evaluation of the anti-inflammatory activity of some medicinal plants growing in Egypt. Med J Islamic World Academy Sci. 2010;18(4):139-50.

2. Ayoola, G.A., G.A. Alpanika, F.O. Awabajo. Anti-inflammatory properties of the fruits of Allanblanckia floribunda olive (guttiferae). Bot Res Int. 2009;2;21-6.

3. Rafik U. Shaikh, Mahesh M. Pund, Rajesh N. Gacche. Evaluation of antiinflammatory activity of selected medicinal plants used in Indian traditional medication system in vitro as well as in vivo. Journal of Traditional and Complementary Medicine. 2016;6(4);355-61.

4. Matos, F. J. A. Introduction a plant experimental.Fortaleza: Edicoes, 1997; 141 p.

5. Bakari, S., M. Ncir, S. Felhi, H. Hajlaoui, M. Saoudi, N. Gharsallah, A. Kadri. Chemical composition and in vitro evaluation of total phenolic, flavonoid and antioxydant properties of essential oil and solvent extract from the aerial parts of Teucrium poliumgrown in Tunisia. Food Science and Biotechnology. 2015;24(6): 1943-9

6. Harborne, J.B. Phytochemical Methods, Chapman and Hall Ltd. London. 1973;8(9):49-188.

7. Adedapo, A.A., F.O. Jimoh, S. Koduru, P.J. Masika, A.J. Afolayan, b. Assessment of the medicinal potentials of the methanol extracts of the leaves and stems of Buddlejasaligna. BMC Compl. Altern Med.2009; 9:21.

8. Reinheimer, Z.A. Reinheimer, M.R. Demkov, M.C. Condioti. Inhibition of coliform bacteria by lactic cultures. Aust. J. Dairy Technol. pp. 1990;5-9

9. Shimada, K., K. Fujikawa, K. Yahara, T. Nakamura. Antioxidative properties of xanthan on the autoxidation of soybean oil in cyclodextrin emulsion. J. Agri. Food Chem. 1992;40:945-8

10. Sana Bakari, HafedhHajlaoui, Amal Daoud, Hedi Mighri, Jose Maria RossGarcia, NejiGharsallah, Adel Kadr.Phytochemicals, antioxidant and antimicrobial potentials and LC-MS analysis of hydroalcoholic extracts of leaves and flowers of Erodium glaucophyllumcollected from Tunisian Sahara. Food Science and Technology. 2018;38(2):310-7.
11. Smirnoff, N. and Q.J. Cumbes. Hydroxyl radical scavenging activity of compatible solutes. Phytochem. 1989;28:1057-60.

12. Zhang, M., L. Wentao and L.Guoying, 2009. Isolation and characterization of collagens from the skin of largefinlongbarbel catfish Mystusmacropterus. Food Chem.2009:115:826-31.

13. Mossman, T. Rapid colorimetric assay for cellular growth and survival: application to proliferation and cytotoxicity assays. J Immunol Methods. 1983;65:55-63.

14. Adebayo, S.A, J.P. Dzoyem, L.J. Shai, J.N. Eloff, 2015. The anti-inflammatory and antioxidant activity of 25 plant species used traditionally to treat pain in Southern African. BMC Complement Altern Med. 2015;5:1-10.

15. Mizushima $Y$ and Kobayashi M, 1968. Interaction of antiinflammatory drugs with serum preoteins, especially with some biologically active proteins. J of Pharma Pharmacol. 1968:20:169-73.

16. Oyedepo, O.O and A.J. Femurewas. Anti-protease and membranestabilizing activities of extracts of Fagrazanthoxiloides, Olaxsubscorpioidesand Tetrapleuratetraptera. In. J. Pharm. 1995;33:65-9

17. Sadique J, W.A. Al-Rqobahs, A.R. Bughaith El-Gindi. The bioactivityof certain medicinal plants on the stabilization of RBS membranesystem. Fitoterapia, 1989;60:525-32.

18. Ohkawa, H, N. Oshishi, K. Yagi. Assay for lipid peroxide in animal tissue by thiobarbituric acid reaction. Anal Biochem, 1979;95:351-8

19. Baran, R. Changes in phenolic compounds and colour in pole cherry wines subjected to fining treatment. Zeitschrift Fur Lebensmittel-Untersuchung Und Forschung. 1997;205(6);474-8.

20. Mello, J. P. C, Phytochemical, plant as medicinal; Ed. UFSC: Porto Alegre; $3^{a}$ ed. 2001.

21. Pamhidzai, D, G. Isaac, G. TLC. Separation, antibacterial and anti-inflammatory activity of extracts derived from Zanthoxylumhumile roots. International Journal of Research in Ayurveda and Pharmacy.2013; 4 (4); 2277-4343.

22. Naumann, D, D. Helm, D and Labischinski,. Microbiological characterizations by FT-IR spectroscopy. Nature, 1991;351:81-2.

23. Abu-Shanab, B, G. Adwan, D. Abu-Safiya, N. Jarrar. Antibacterial activities of some plant extracts utilized in popular medicine in Palestine. Turk. J. Biol 2004;28:99-102.

24. Laopaksa, A., S. Amnuoypol and V. Jongboonprasert. Preliminary study on antibacterial action of Thai medicinal plants for respiratory tract infection (I). Thai J. Pharm. Sci.1988:13:23-36.

25. Kinsella, A.R., B. Green Lepts, G.C. Hill, C.G. Bowie and B.A. Taylor. The role of the cell-cell adhesion molecule E-cadherin in large bowel tumour cell invasion and metastasis. Br. J. Cancer., 1993;67:904-9.

26. Leelaprakash G and S. Mohan Dass. Invitro anti-inflammatory activity of methanol extract of Enicostemmaaxillare. International Journal of Drug Development and Research. 2011;3(3);0975-9344.

27. Govindappa, M, S. Naga Sravya, M.N. Poojashri, T.S. Sadanandaand C.P. Chandrappa, 2011. Antimicrobial, antioxidant and in vitro anti-inflammatory activity of ethanol extract and active phytochemical screening of Wedeliatrilobata. Journal of Pharmacognosy and Phytotherapy, 2011;3(3):43-51.

28. Nirmala $P$ and T. Selvaraj. Anti-inflammatory and anti-bacterial activities of Glycyrrhiza glabra. Journal of Agricultural Technology.2011;7(3):815-23. 


\section{GRAPHICAL ABSTRACT}

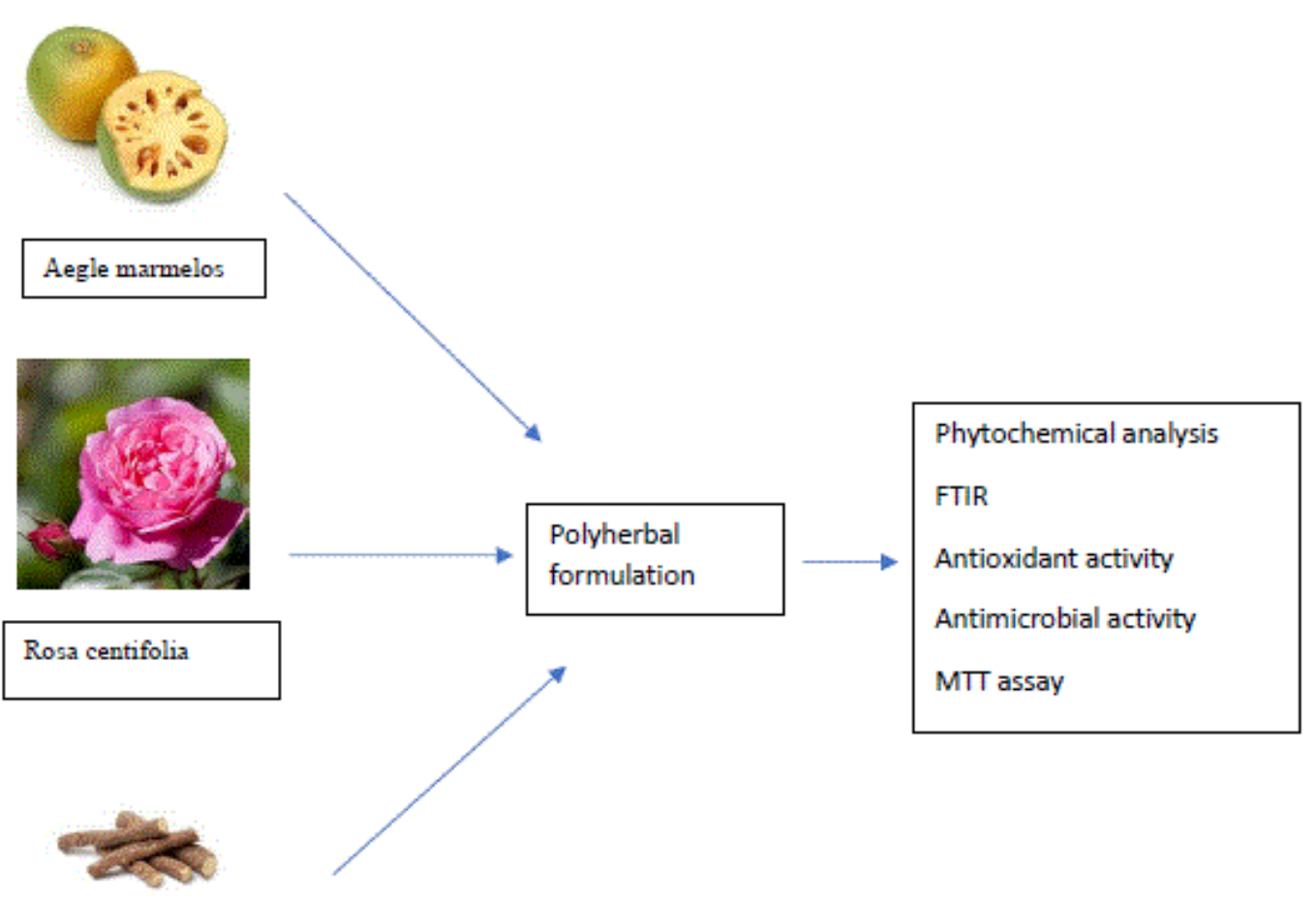

Glycyrrhiza glabra

\section{ABOUT AUTHORS}

\section{- Mr. VASANTH M.P}

Vasanth M. P is a research scholar under the guidance of Associate prof. Dr. purusotham K.G at Department of Biotechnology, Dr.M.G.R. Educational and Research Institute India. He completed his postgraduate in Biotechnology Sri Ramachandra University India. He has good knowledge in the field of molecular biology, toxicology, herbal compounds, immunology. At present his research area is Bioactive herbal compounds on immunological studies.

\section{- Dr. purusotham K.G}

Department of biotechnology Dr.M.G.R. Educational and research institute India.

Cite this article: Vasanth MP, Purushotham KG. Screening of Phytochemical Analysis and In vitro Bioactive of Polyherbal Formulation. Pharmacogn J. 2020;12(6)Suppl:1525-33. 